\title{
Congenital syphilis in Marabá (State of Pará, Brazil): epidemiological analysis of a decade
}

\section{Caroline Mendes Santos ${ }^{1}$ and Daniela Soares Leite ${ }^{2}$}

${ }^{1}$ Universidade do Estado do Pará - UEPA. Curso de Biomedicina. Centro de Ciências Biológicas e da Saúde. Campus VIII. Avenida Hileia, S/№. Agrópolis do Incra. Bairro Amapá. Marabá-PA, Brazil (CEP 68502-100).

${ }^{2}$ Universidade do Estado do Pará - UEPA. Centro de Ciências Biológicas e da Saúde. Campus VIII. Departamento de Morfologia e Ciências Fisiológicas. Avenida Hileia, S/№. Agrópolis do Incra. Bairro Amapá. Marabá-PA, Brazil (CEP 68502-100). Email: danielaleite@uol.com.br.

\begin{abstract}
Congenital syphilis (CS) is a systemic infect contagious disease, sexually transmitted, easily diagnosed, with effective and low cost treatment. Thus, the existence of a paradox is detached, once infectious diseases of greater complexity have already been controlled. In its congenital form, syphilis in Brazil constitutes a sentry event of high magnitude that presents unfavorable indicators in terms of its control. In the State of Pará, Marabá is the municipality with the highest number of cases in the past years. The aimed of this study was describing a clinical-epidemiological profile of congenital syphilis in Marabá, from 2006 to 2015. This was a descriptive, retrospective and documental study which analyzed secondary data from SINAN/SMS/SVS/DATASUS/Marabá/PA. Between 2006 and 2015, 323 cases of CS were notified in Marabá. The incidence of congenital syphilis of 6.5 cases per 1,000 live births from 20062015 is 6.5 the Ministry of Health goal; from 2012 to 2015 the rates were $8,9.8,26.3$ and 11.3/1,000, respectively. Most pregnant women performed prenatal $(88.6 \%)$, was between 20 and 24 years old $(62.2 \%), 26.6 \%$ did not finish Middle School. Most partners, $67.5 \%$, of the pregnants diagnosed with did not perform treatment; in $55 \%$ of cases, the maternal syphilis diagnosis happened during labor/curettage. Congenital syphilis in Marabá overcame the highest incidence in 2014, with 26.3 cases per 1,000 live births. This great value in 2014 may be a result of the campaign "It's possible to born without syphilis in Pará", released by the Secretary of State for Health of Pará at the end of 2013, since in periods of huge campaigns there is an increase of notifications, due to easier access to the diagnosis of the disease. In the year of 2015, an incidence of 11.3 cases per 1,000 live births was observed, this abrupt decrease, compared to 2014 , corroborates with the influence of the campaigns in the detection of new cases. The cases of congenital syphilis notified in the Municipality of Marabá demonstrated failures in the prenatal service, particularly in the time of verification of gestational syphilis and in the treatment of the partners.
\end{abstract}

Received

March 01, 2018

Accepted

April 02, 2018

Released

April 30, 2018

Full Text Article

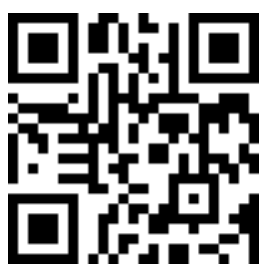

ORCID

(D) 0000-0002-2442-0179

Caroline Mendes Santos

(D) 0000-0002-3412-1375 Daniela Soares Leite 
However, most cases had a positive outcome, with a low number of pre and perinatal deaths due to CS. According to the section of Epidemiological Surveillance of Marabá, many factors are responsible for the high incidence of congenital syphilis in the municipality, among them the lack of clarification of the pregnants/mothers about syphilis, a low demand by the prenatal care and the low attendance of partners, what unfeasible the effective control of this disease, as well as the precarious training of health professionals, who give little importance to the disease and show difficulty to interpret lab results. The correct notification (if there is a higher quality in the reports, the number will be closer to the real), investigation of cases, appropriate treatment and implementation of measures to prevent new cases of congenital syphilis will contribute to the reduction of cases in Marabá.

Keywords: Congenital Syphilis; Prenatal Care; Health Promotion.

\section{Introduction}

The sexually transmitted infections (STIs) represent a global concern because of the increasing number of cases per year (Donalísio et al., 2007). According to World Health Organization (WHO), that are about 12 millions of new cases per year, and syphilis represents a huge number of them (OMS, 2008). The syphilis is a systemic, infectious and contagious disease, sexually transmitted, with easy diagnosis, effective and inexpensive treatment. Thereby, points to the existence of a paradox, seeing that more complex contagious diseases were already control (Matthes et al., 2010).

The syphilis etiologic agent is the Treponema pallidum bacteria and the evolution of the illness has three stages: primary, secondary and tertiary, and between the two final stages occurs latency period that can last years, with absence of symptoms (WHO, 2008).

In newborns, congenital syphilis (CS) can be distinct in two stages: early and late. The early-stage happens when the sings of the disease appear until the first two years old. The late-stage happens when the symptoms appear after the second year of life. Biggest part of the live births doesn't have symptoms, however the adversities observed in those newborns include cutaneous lesion, low weight, hepatic/ splenomegaly, prematurity, respiratory distress, etc. The Ministry of Health recommended treatment includes the administration of penicillin G (crystal or procaine) and the therapeutic system changes according to the clinical conditions. The diagnosis in newborns should be done by the serology Venereal Disease Research Laboratory (VDRL), radiograph of long bones and blood and cerebrospinal fluid analysis (Brasil, 2008).

Among all the diseases that can be transmitted during the pregnancypuerperal cycle, the syphilis has the higher infections rates. Spontaneous abort, stillborn fetus or perinatal death are present in $40 \%$ of the children infected by non-treat mothers (Brasil, 2006). The occurrence of CS demonstrates deficits in the prevention of syphilis in the public health system, mainly in the prenatal care. The serology diagnosis with VDRL of the pregnant must be requested in the $1^{\circ}$ and $3^{\circ}$ trimesters of pregnancy. The treatment is 
done with penicillin and the therapeutic scheme is defined according to the clinical evaluation (Brasil, 2010).

The numbers of CS cases in Brazil are expressive. From 1998 to June of $2014,104,853$ cases of early CS were notified in SINAN (National Information System on Diseases of Notification or Sistema de Informação de Agravos de Notificação). Among them 48,015 (45.8\%) in Southeast, 32,884 (31.4\%) in Northeast, 8,959 (8.5\%) in South, 8,856 $(8.4 \%)$ in North and 6,139 (5.9\%) in Midwest Region.

According with the Sespa (Secretary of State for Health of Pará or Secretaria de Estado de Saúde Pública do Pará), from 2010 to 2014, the State of Pará notified 5,191 cases of syphilis in pregnant women, in 134 cities. The cities with the highest case numbers of syphilis during pregnancy in that period were Marabá, Parauapebas and Itaituba. The cities with more cases of CS between 2010 and 2014 were Marabá, Belém and Parauapebas. In both cases (CS and syphilis during pregnancy) Marabá presents the highest numbers of State of Pará, considering that also were notifications of patients who lives in towns that are close to the municipality (Sespa, 2015).

Those indicators can be a reflection of the low quality of the prenatal care and the short importance that the health professionals give to the early diagnosis and treatment of syphilis. Stressed that the prevention of the disease is simple and unexpressive, the treatment of a child with CS is long and onerous (Damasceno et al., 2014). The treatment of the pregnant women, which should be done during the pregnancy, is also faulty, despite is available for free in Brazil's Unified Health System (Sistema Único de Saúde). Social vulnerabilities and inequality in access to health care are pointed as substantial coefficients to the prevalence of CS (Cunha and Merchan-Hamann, 2015). Brazil is a signatory of the global agreement that intended the control and eradication of syphilis until 2015. In this accordance, the incidence of congenital syphilis should be less than 0.5 cases by 1,000 newborns per year until 2015 (Brasil, 2015).

According to the numbers presented to Brazil, to State of Pará and the Municipality of Marabá, is important an epidemiological study about CS that intend to identify probable causes of the increasing in the incidence, failures that cause the vertical transmission of syphilis and to propose measures that help in the prevention, assistance and vigilance of that disease. Thus, this study may assist the Municipal Health Secretary of Marabá (Secretaria de Saúde de Marabá) in the better targeting of the congenital syphilis prevention campaigns.

The aimed of this study was provide an epidemiological study of the notified cases of congenital syphilis in the Municipality of Marabá, State of Pará, between in the period of 2006 to 2015, through the recorded data in three health information systems (SINAN, SIM and SINASC) and data from Municipal Health Secretary of Marabá.

\section{Materials and methods}

This was a descriptive, retrospective and documental study, which analyzed secondary data of all congenital syphilis cases that were notified in Municipal Health Secretary of Marabá from 2006 to 2015. The data were consulted by the following Brazil's Unified Health System information systems: National Information System on Diseases of Notification (SINAN), Mortality Information System (SIM) and Live Birth Information System (SINASC), all available in the platform DATASUS (Information Technology Department of the Unique System of Health). In cases of contrariety among the data registered in SINAN and the information was given by the Municipal Health Secretary of Marabá, was given preference to the SINAN data. 
The following variables were investigated: maternal age, maternal schooling, accomplishment of prenatal, verification of maternal syphilis, partners' treatment, maternal treponemal test, neonate treatment and development. All congenital syphilis cases notified in Marabá from 2006 to 2015 were included.

A single database was built using the data from SINAN and Municipal Health Secretary of Marabá. The CS annual incidence was calculated using the number of cases by 1,000 newborns in each year. The results were exhibited in relatives and absolutes frequencies.

The present paper has been approved by the Human Research Ethics Committee of Health and Biological
Sciences Center, in the University of State of Pará (approval number 67565517.9.0000.5174), what assure its commitment with the ethic commandments presented in National Health Council Resolution No. 466/2012 (Brasil, 2012), that provides the guidelines to research that involves humans.

\section{Results}

During Jan. 01, 2006, and Dec. 31, 2015,323 cases of congenital syphilis (CS) were notified in Marabá, including the early and late mode and abortions caused by syphilis. The lower incidence was registered in 2006, and the highest, in 2014. The CS incidence is shown in Figure 1.

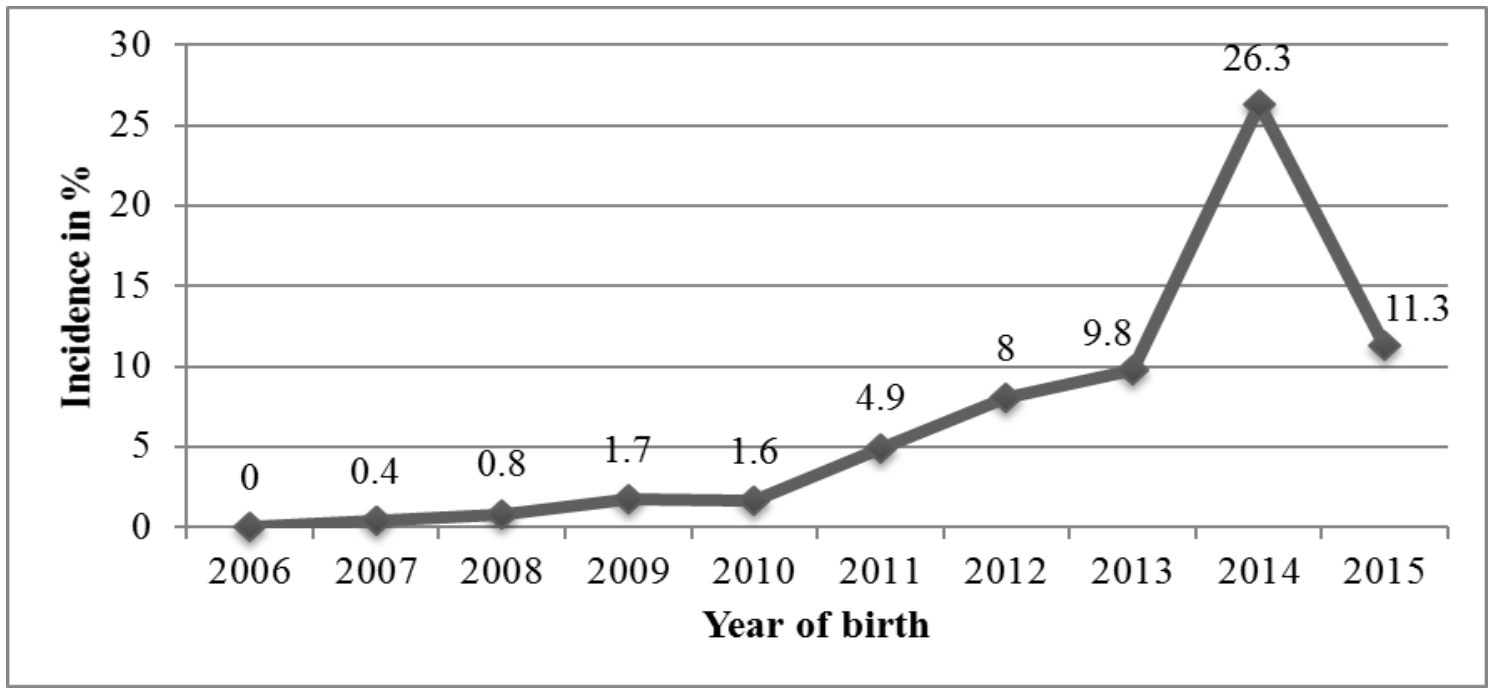

Figure 1. Incidence of congenital syphilis in the Municipality of Marabá, calculated using the number of cases notified in SINAN by 1.000 newborns in each year.

Table 1 resumes the CS epidemiology in the Municipality of Marabá. It includes data from SINAN and Municipal Health Secretary of Marabá. Through the data it's possible to realize that most part of mothers with children with CS accomplish prenatal (86.6\%), however the syphilis diagnosis of $55.1 \%$ of them was given during labor/ curettage. The treponemical tests of the largest part of mothers (67\%) were reactive. Most partners did not get treatment, totaling $67.5 \%$. About the newborns the born with CS, $96.3 \%$ of them born alive and $76 \%$ received the diagnosis of early CS. Most, $37.2 \%$, of the newborns were treated with penicillin $\mathrm{G}$ cristal. Around $37 \%$ of the mothers had unfinished Middle School and 62.2\% were between 20-34 years old. 
Table 1. Epidemiological profile of congenital syphilis in Marabá, with data from SINAN and Municipal Health Secretary of Marabá, from 2006 to 2015.

\begin{tabular}{|c|c|c|}
\hline Variable & $\mathbf{N}$ & $\%$ \\
\hline \multicolumn{3}{|l|}{ Prenatal care } \\
\hline Unknown & 24 & 5.8 \\
\hline Performed & 339 & 81.6 \\
\hline Unperformed & 52 & 12.5 \\
\hline \multicolumn{3}{|l|}{ Maternal syphilis } \\
\hline Unknown & 20 & 5.0 \\
\hline During prenatal care & 148 & 36.4 \\
\hline Labor/curettage & 224 & 55.1 \\
\hline After delivery & 10 & 2.4 \\
\hline Não realizado & 4 & 0.9 \\
\hline \multicolumn{3}{|c|}{ Treponemal test (pregnant/mother) } \\
\hline Unknown & 114 & 13.3 \\
\hline Reactive & 571 & 67.0 \\
\hline Non-reactive & 26 & 3.0 \\
\hline Unrealized & 141 & 16.5 \\
\hline \multicolumn{3}{|l|}{ Partner's treatment } \\
\hline Unknown & 114 & 20.7 \\
\hline Yes & 65 & 11.8 \\
\hline No & 372 & 67.5 \\
\hline \multicolumn{3}{|l|}{ Final diagnosis (neonate) } \\
\hline Unknown & 25 & 6.0 \\
\hline Early CS & 309 & 76.0 \\
\hline Late CS & 1 & 0.2 \\
\hline Stillborn/abort for syphilis & 13 & 3.2 \\
\hline Discarded & 58 & 14.2 \\
\hline \multicolumn{3}{|l|}{ Development (neonate) } \\
\hline Unknown & 6 & 1.5 \\
\hline Alive & 367 & 96.3 \\
\hline Death by CS & 7 & 1.8 \\
\hline Death by other causes & 1 & 0.2 \\
\hline \multicolumn{3}{|l|}{ Treatment (neonate) } \\
\hline Unknown & 29 & 5.7 \\
\hline Penicillin G Cristal & 189 & 37.2 \\
\hline Penicillin G Procaine & 2 & 0.4 \\
\hline Penicillin G Benzathine & 119 & 23.4 \\
\hline Other treatment & 92 & 18.0 \\
\hline Unrealized & 76 & 15.0 \\
\hline \multicolumn{3}{|l|}{ Schooling (pregnant/mother) } \\
\hline Unknown & 32 & 7.6 \\
\hline Illiterate & 1 & 0.2 \\
\hline Until 8 years of study & 87 & 20.6 \\
\hline Until 12 years of study & 156 & 37.0 \\
\hline Until 15 years of study & 124 & 29.4 \\
\hline 19 years of study or more & 9 & 2.1 \\
\hline \multicolumn{3}{|l|}{ Age (pregnant/mother) } \\
\hline Unknown & 8 & 1.8 \\
\hline 10 to 14 years old & 13 & 2.5 \\
\hline 15 to 19 years old & 138 & 26.7 \\
\hline 20 to 34 years old & 321 & 62,2 \\
\hline 35 to 49 years old & 35 & 6,7 \\
\hline
\end{tabular}




\section{Discussion}

The cases of congenital syphilis (CS) notified in the Municipality of Marabá show failures in the prenatal care, mainly in the verification moment of syphilis during pregnancy of the partners' treatment. Although, most of the cases had a positive outcome, with lower numbers of deaths by CS before and after birth.

The incidence of CS in Marabá reached the highest scores in 2014, with 26.3 cases per 1,000 live births. This high number in 2014 can be a result of the campaign against congenital syphilis, developed by Secretary of State for Health of Pará (Sespa) in the end of 2013, called "It's possible to born without syphilis in Pará" (É possível nascer no Pará sem sífilis), whereas periods of huge campaigns occurs rising in the notifications, because the greater ease in the disease's diagnosis. In 2015, that was an incidence of 11.3 per 1,000 live births and that abrupt reduction regarding 2014 corroborates with the influence of campaigns in the diagnosis of new cases (Sespa, 2013). Despite the decrease of notified cases, the CS incidence in 2015 was 11.3, a number far from the recommend by Pan American Health Organization (PAHO) and United Nations Children's Fund (UNICEF), an incidence of 0.5 cases per 1,000 live births until 2015 (Brasil, 2015).

According to the section of Epidemiological Surveillance of Marabá, many factors are responsible for the high incidence of congenital syphilis in the municipality, among them the lack of clarification of the pregnants/mothers about syphilis, a low demand by the prenatal care and the low attendance of partners, what unfeasible the effective control of this disease. According to Milanez (2016), the main problem to the control of syphilis during pregnancy is in the precarious training of health professionals, who give little importance to the disease and show difficulty to interpret lab results. The failure in the partners' treatment also is a factor to the permanency of the disease, as well as the ineffective pregnants' treatment (Milanez, 2016).

During the data analysis, the number of pregnant women who accomplish the prenatal (88.6\%) overcame those who did not or those who that variable was unknown. Despite this, the number of women whose children had CS and that did not do prenatal developed, going to 1 notified case in 2011 to 22 cases in 2015. A hospital-based cohort study performed by Domingues et al. (2014), verified that North region had the second worse prenatal coverage in Brazil, a factor that may be related to cultural and socioeconomic hurdles, once the less attended groups were indigenous and low income women. Almeida (2012) verified that in State of Ceará, Northeast Brazil, about $70 \%$ of pregnant women performed prenatal and among those who did not, the main reason was unconcern, described by the pregnants in many forms: lack of time or companion, undesirable pregnancy, never had done prenatal, etc.

In $55 \%$ of cases, the diagnosis of maternal syphilis occurs during labor/curettage, a factor that dissents of the verified in Macapá (State of Amapá), where the most diagnosis occurs during prenatal $(36.8 \%)$ or after delivery (35.8\%) (Francisco, 2014). Lima et al. (2016) ascertain that most (62.1\%) syphilis during pregnancy diagnosis were performed in prenatal. In 2015 the Municipality of Marabá showed a decrease in the number of mothers who diagnosed syphilis during prenatal, what is worrisome because this health service provides the ideal time to the diagnosis and treatment of various diseases, in addition to health promotion to the mother and the unborn. The nonaccomplished of VDRL during prenatal - 
pointed by the number of mothers who had the syphilis diagnosis during labor/curettage - it's contrary to the Ministry of Health, that recommend the accomplishment of two VDRL tests during pregnancy, one in the first trimester and other in the third one (Lima et al., 2017). Must consider that most pregnant women infected by T. pallidum are in the latency period of the disease, with absence of symptoms, being a responsibility of the health professionals require for the VDRL (Milanez, 2016).

The treponemal test is a significant factor to the syphilis diagnosis in false-positive or false-negative cases, what can happen in non-treponemal tests (Brasil, 2006). Among the pregnants/mothers who did the treponemal test, $67.0 \%$ presented reactive result and in $16.5 \%$ of cases, this test was not performed. This data is compatible with Teixeira et al. (2015).

Most of the partners (67.5\%) of the pregnant women with syphilis did not perform treatment and the second most $(20.6 \%)$ had this information unknown in the notification record. The number of unknowns went from zero in 2012 to 76 in 2015, increasing more than the number of partners who got treatment. Lima et al. (2017) and Souza et al. (2016) presented similar congenital syphilis data in Sobral (State of Ceará) and in Brazil, respectively. Those numbers go against gainsay of Teixeira et al. (2015) in Chapadão do Sul (State of Minas Gerais), where $50 \%$ of partners were treated with the pregnant and, among those who did not be treated, the reason was unknown. The undone partner treatment is one of the main obstacles to the of syphilis elimination because it provides reinfection of the pregnants. Studies indicates that the difficulty of partners to get involve in treatment can be related to the misunderstanding of what the disease will cause in the mother and the unborn's life or to the fact that the public health service concerns to congenital syphilis have not specific initiatives to the male public (Lima et al., 2017; Mesquita et al., 2012).

Most of the newborns (76.0\%) whose mothers had syphilis got the diagnosis of early CS, with only one case of late CS, what agrees with the epidemiology of CS in Macapá (Francisco, 2014). The smaller number of cases of late CS is probably related to the penicillin therapy, that is capable to provide a less aggressive form of the disease (Flores, 2011).

Majority of cases, $96.3 \%$, have not neonatal death, what concurs with the CS epidemiological profile describes in current literature (Domingues and Leal, 2016; Rojas et al., 2015). The aborts for syphilis are frequently related to neurosyphilis or bone injuries, variables often ignored in the notification records (Saraceni and Leal, 2016). Researchers pointed those notifications of deaths caused CS may do not correspond with reality since little is known about the evolution of the newborn's condition after discharge (Rojas et al., 2015).

In $37.2 \%$ of cases, the neonates diagnosed with syphilis were treated with penicillin $\mathrm{G}$ crystal, in a therapeutic scheme of 100,000 to $150,000 \mathrm{Ul} \mathrm{kg} /$ day during 10 days. The penicillin G benzathine - administrated in the absence of symptoms and clinical, laboratorial, radiological and serological alterations - were prescribed in $23.4 \%$ of cases. Although the treatment were not performed in $15.0 \%$ of cases only, it's important to inquire the reasons that lead to this situation, because the nonaccomplished of the treatment in up to three months can cause severe damage to the child (Flores, 2011).

Regarding mothers' schooling, most $(26.6 \%)$ did not finish fifth through eighth grade of Middle School, what agrees with Francisco (2014) in a study of the epidemiological profile of syphilis during pregnancy in Macapá. The low level of instruction is usually associate with low socioeconomic class, what expose the pregnant/mother to social 
risk factors, as unemployment, chaotic urbanization and inequality (Flores, 2011; Souza and Benito, 2016). In 2015, the number of pregnant women who had finished High School overcame those who hadn't, what shows a change in the congenital syphilis epidemiological profile in Marabá. Such fact is concerning since this part of the population should have greater knowledge about Sexually Transmitted Infections (Souza and Benito, 2016). The number of unknown education developed, going from none in 2012 to 13 in 2015, a detrimental factor to the Epidemiological Surveillance and an evidence of health professionals potential default.

Most pregnants with syphilis were between 20 to 34 years old, totalizing $62.2 \%$ of notified cases. That goes against Teixeira et al. (2015) in an analysis of syphilis during pregnancy data in Chapadão do Sul (State of Mato Grosso do Sul), where most women that presented syphilis during pregnancy were 15 to 25 years old. The data found agrees with the age profile of syphilis during pregnancy in Aracaju (State of Sergipe), Fortaleza and in the State of Ceará (Almeida, 2012; Santos et al., 2016). This age range is the most fertile and with the higher numbers of gestations, what agrees with what was found in this study.

The central issue in this study was the discrepancy between the data present by the Municipal Health Secretary of Marabá and those recorded in SINAN, since those registered in a municipality level were higher than those that were available in DATASUS. This fact suggests an underreporting problem in SINAN, what harms the epidemiological attendance and studies that use SINAN as data source. Ramos Junior et al. (2007) evaluate that the underreporting in SINAN may come to $67.0 \%$ per year. Lafetá et al. (2016) verified that only $24.1 \%$ of CS cases were notified. The inaccurate filled of notification forms is another SINAN failure pointed by studies, what damnify the action of
Epidemiological Surveillance and the control of the diseases of mandatory notification in Brazil (Flores, 2011).

Researchers indicate that the control of syphilis in the country still precarious, obtained less success than the control of AIDS (Acquired Immunodeficiency Syndrom). The necessary approach to that would be in a better training to the health professionals and more information and education about the disease for the population (Ramos Junior et al., 2007). In a study with mothers of child who were born with congenital syphilis, Lima et al. (2016) estimate that the low schooling and the little information provide by the health professionals about the riskiness of the T.pallidum infection were determinants to the little adhesion to treatment or incorrect treatment (Lima et al., 2016).

The presented data verified that the accomplishment of prenatal in Marabá pointed for a low resolubility of the Basic Attention concerning to women health and should be investigated, once the achievement of prenatal is usually associate with a small number of congenital syphilis cases. The nonachievement of partners' treatment pointed to the necessity of training to the Marabá Basic Attention health professionals, focused on the importance of request VDRL during prenatal, the presence of the partner and the correct fill of the syphilis notification form. Moreover, the low level of education of the pregnants/mothers indicates that improvements in the quality of life can act in a good way to decrease CS, although the educational profile change in 2015 suggests that the more educated pregnants/mothers may have not satisfactory health education and did not know the severity of CS. The data from this study can help in the elaboration of public health campaigns against syphilis and congenital syphilis that had greater accuracy, directed for the more vulnerable population groups and adjustments of the prenatal failures. 


\section{Conclusions}

The findings in this study show that congenital syphilis still a huge problem in the public health of Marabá. The average incidence rates were above the national established parameter. Thus, correct notification (if it is a better quality in the notification, the numbers of cases will be closer of the real), investigation of cases, adequate treatment, implementation of measures to prevent new cases of congenital syphilis will contribute to the decrease of cases towards the elimination of this disease in Marabá.

\section{Acknowledgments}

To the Municipal Health Secretary of Marabá, for the logistical support to this study achieve.

\section{Conflict of interest statement}

Authors declare that they have no conflict of interests.

\section{References}

Almeida, F. C. M. Transmissão vertical da sífilis: análise dos fatores intervenientes na morbimortalidade. Fortaleza: Universidade Estadual do Ceará, 2012. (M. Sc. Thesis).

Brasil. Ministério da Saúde. Coordenação de Doenças Sexualmente Transmissíveis e Aids. Série TeleLab. Sífilis: Estratégias para Diagnóstico no Brasil. Brasília: MS, 2010.

Brasil. Ministério da Saúde. Secretaria de Vigilância em Saúde. Departamento de DST, Aids e Hepatites Virais. Boletim Epidemiológico: Sífilis. Brasília: MS, 2015.

Brasil. Ministério da Saúde. Secretaria de Vigilância em Saúde. Programa Nacional de DST e Aids. Diretrizes para o controle da sífilis congênita: manual de bolso. Brasília: MS, 2006.

Brasil. Ministério da Saúde. Serviço de Vigilância Epidemiológica. Coordenação do Programa Estadual DST/Aids-SP. Coordenadoria de Controle de Doenças. Secretaria de Estado da Saúde. Informes Técnicos Institucionais. Sífilis congênita e sífilis na gestação. Revista de Saúde Pública, v. 42, p. 768-772, 2008.

Brasil. National Council of Health. Resolution No. 466, of 12 December 2012. Available from: <http://conselho.saude.gov.br/ resolucoes/2012/466_english.pdf>. Accessed on: Jul. 23, 2017.

Cunha, A. R. C.; Merchan-Hamann, E. Sífilis em parturientes no Brasil: prevalência e fatores associados, 2010 a 2011. Revista Panamericana de Salud Pública, v. 38, p. 479-486, 2015. Available from: <https://scielosp.org/pdf/rpsp/v38n6/v38n 6a07.pdf>. Accessed on: Jul. 23, 2017.

Damasceno, A. B. A.; Monteiro, D. L. M.; Rodrigues, L. B.; Barmpas, D. B. S.; Cerqueira, L. R. P.; Trajano, A. J. B. Sífilis na gravidez. Revista Hospital Universitário Pedro Ernesto, v. 13, p. 88-94, 2014. https://doi.org/10.12957/rhupe.2014.1213

Domingues, R. M. S. M.; Leal, M. C. Incidência de sífilis congênita e fatores associados à transmissão vertical da sífilis: dados do Estudo Nascer no Brasil. Cadernos de Saúde Pública, v. 32, p. 2-12, 2016. https://doi.org/10.1590/0102-311X00082415

Domingues, R. M. S. M.; Szwarcwald， C. L.; Souza Junior, P. R. B.; Leal, M. C. Prevalência de sífilis na gestação e testagem pré-natal: Estudo Nascer no Brasil. Revista de Saúde Pública, v. 48, p. 766-774, 2014. https://doi.org/10.1590/S0034-8910.20140 48005114

Donalísio, M. R.; Freire, J. B.; Mendes, E.T. Investigação da sífilis congênita na Microrregião de Sumaré, Estado de São Paulo, Brasil: desvelando a fragilidade do cuidado à mulher gestante e ao recémnascido. Epidemiologia e Serviços de Saúde, v. 16, p. 165-173, 2007. https://doi.org/10.5123/S1679-49742007 000300003

Flores, R. L.R. Sífilis congênita no Município de Belém (Pará): análise dos dados registrados nos sistemas de informação em saúde (SINAN, SIM e SINASC). Rio de Janeiro: Fundação Oswaldo Cruz, 2011. (M. Sc. Thesis).

Francisco, V.C.C. Sífilis Congênita no município de Macapá/AP: análise dos dados registrados no Sistema de Agravos de Notificação (SINAN), no período de 2007 a 2012. Macapá: Universidade Federal do Amapá, 2014. (M. Sc. Thesis). 
Lafetá, K. R. G.; Martelli Júnior, H.; Silveira, M. F.; Paranaíba, L. M. R. Sífilis materna e congênita, subnotificação e difícil controle. Revista Brasileira de Epidemiologia, v. 19, p. 63-74, 2016. https://doi.org/10.1590/ 1980-5497201600010006

Lima, V. C.; Mororó, R. M.; Feijão, D. M.; Frota, M. V. V.; Martins, M. A.; Ribeiro, S. M.; Linhares, M.S. C. Percepção de mães acerca da sífilis congênita em seu concepto. Revista de Saúde Pública do Paraná, v. 17, p. 118125 , 2016. https://doi.org/ 10.22421/1517-7130.2016v17n2p118

Lima, V. C.; Mororó, R. M.; Martins, M. A.; Ribeiro, S. M.; Linhares, M. S. C. Perfil epidemiológico dos casos de sífilis congênita em um município de médio porte do nordeste brasileiro. Journal of Health \& Biological Sciences, $\quad$ v. 5, p. 56-61, 2017. https://doi.org/10.12662/2317-3076jhbs. v5i1.1012.p.56-61.2017

Matthes, A. C. S.; Lino, A. P. S.; Costa, C. A.; Mendonça, C. V.; Bel, D. D. Sífilis congênita: mais de 500 anos de existência e ainda uma doença em vigência. Pediatria Moderna, v. 48, No. 4, p. 149-154, 2010. Available from: <http://www.moreirajr.com.br/revistas.asp? fase $=$ r003\&id_materia $=4977>$. Accessed on: Jul. 23, 2017.

Mesquita, K. O.; Lima, G. K.; Filgueira, A. A.; Flôr, S. M. C.; Freitas, C. A. S. L.; Linhares, M.S. C.; Gubert, F. A. Análise dos casos de sífilis congênita em Sobral, Ceará: contribuições para assistência pré-natal. Jornal Brasileiro de Doenças Sexualmente Transmissíveis, $\quad$ v. $24, \quad$ p. 20-27, 2012. https://doi.org/10.5533/2177-8264-201224 107

Milanez, H. Syphilis in pregnancy and congenital syphilis: why can we not yet face this problem? Revista Brasileira de Ginecologia e Obstetrícia, v. 38, p. 425-427, 2016. https://doi.org/10.1055/s-0036-1593 603

OMS - Organização Mundial de Saúde. Eliminação Mundial da Síflis Congénita: fundamento lógico e estratégia para acção. Genebra: OMS, 2008. Available from: <http://apps.who.int/iris/bitstream/10665/ 43782/4/9789248595851_por.pdf>.

Accessed on: Jul. 23, 2017.
Ramos Junior, A. N.; Matilda, L. H.; Saraceni, V.; Veras, M. A. S.; Pontes, R. J. S. Control of mother-to-child transmission of infectious diseases in Brazil: progress in HIV/AIDS and failure in congenital syphilis. Cadernos de Saúde Pública, v. 23, p. 370-378, 2007. https://doi.org/10.1590/S0102-311X2007 001500005

Rojas, M. M.; Dias, R. M.; Araújo, E. C. Dez anos de sífilis congênita em maternidade de referência na Amazônia brasileira. Revista Paraense de Medicina, v. 29, p. 7-10, 2015. Available from: <http://files.bvs.br/upload/ S/0101-5907/2015/v29n1/a4651.pdf>. Accessed on: Jul. 23, 2017.

Santos, G. S.; Oliveira, L. X.; Guimarães, A. M. A. N.; Nardello, D. M.; Braz, J. M.; Barreto, I. D. C. Epidemiological aspects of congenital syphilis associated with maternal education. Revista de Enfermagem UFPE, v. 10 , p. $2845-2852$, 2016. https://doi.org/ 10.5205/1981-8963-v10i8a11352p2845-

2852-2016

Saraceni, V.; Leal, M. C. Avaliação da efetividade das campanhas para eliminação da sífilis congênita na redução da morbimortalidade perinatal: Município do Rio de Janeiro, 1999-2000. Cadernos de Saúde Pública, v. 19, p. 1341-1349, 2013. https://doi.org/10.1590/S0102-311X20030 00500012

Sespa comemora Dia da Mulher com ações na praça da República. In: Secretaria de Estado de Saúde Pública. 2015. Available from: <http://www.saude.pa.gov.br/?p=731>. Accessed on: Sept. 29, 2017.

Sespa lançará campanha de combate à Sífilis Congênita. In: Agência Pará Brasil. 2013. Avaliable from: <http://www.agenciapara. com.br/Noticia/62802/sespa-lancaracampanha-de-combate-a-sifilis-congenita>. Accessed on: Sept. 29, 2016.

Souza, W. N.; Benito, L. A. O. Perfil epidemiológico da sífilis congênita no Brasil no período de 2008 a 2014. Universitas: Ciências da Saúde, v. 14, p. 97-104, 2016. https://doi.org/10.5102/ucs.v14i2.3811 
Teixeira, S. R. S.; Queiroz, A. P. Prevalência de sífilis em gestantes no Município de Chapadão do Sul-MS. Visão Universitária, v. 2, p. 14-26, 2015. Available from: <http://www.visaouniversitaria.com.br/ojs/ index.php/home/article/view/53/34>.

Accessed on: Sept. 29, 2016.

License information: This is an open-access article distributed under the terms of the Creative Commons
(CC) Attribution License, which permits unrestricted use, distribution, and reproduction in any medium, provided the original work is properly cited.

Braz. J. Biol. Sci., 2018, v. 5, No. 9, p. 183-193. 